\title{
Spectral detection of nematodes in soybean at flowering growth stage using unmanned aerial vehicles
}

\author{
Bruno Henrique Tondato Arantes ${ }^{*}$ (iD) Victor Hugo Moraes ${ }^{2}$ Alaerson Maia Geraldine ${ }^{2}$ \\ Tavvs Micael Alves ${ }^{2}$ iD Alice Maria Albert ${ }^{2}$ Gabriel Jesus da Silva ${ }^{2}$ Gustavo Castoldi ${ }^{2}$
}

${ }^{1}$ Universidade Federal do Rio Grande do Sul (UFRGS), 91501-970, Porto Alegre, RS, Brasil. E-mail: tondatobh@gmail.com. *Corresponding author. ${ }^{2}$ Instituto Federal Goiano (IF), Rio Verde, GO, Brasil.

ABSTRACT: Soybean is one of the main crop species grown in the world. However, there is a decline in productivity due to the various types of stress, including the nematodes Heterodera glycines and Pratylenchus brachyurus. The objectives were to determine the best spectral band for detecting H. glycines and P. brachyurus at the beginning of flowering (R1). Soil and root sampling was conducted at nine sampling sites in each of the five nematode-infested regions, totaling 45 sampling points. Flights were made at all regions using Phantom 4 Advanced, Sequoia and 14-band customized Sentera. For H. glycines, the red spectral band best explained the variability on soil and root nematode counts as well as the second stage of juveniles in soil. For P. brachyurus, Sentera RedEdge best explained the variability in root nematode counts and Sequoia NIR best explained soil juveniles. A multiple linear regression model using spectral data for detecting P. brachyurus and H. glycines improved $R^{2}$ compared to simple linear regressions. At flowering growth stage (RI), soybean spectral reflectance was associated with the number of $H$. glycines and P. brachyurus on soil and roots using low-cost and multispectral sensors.

Key words: Glycine max, drones, remote sensing, precision farming, integrated management.

Deteç̧ão espectral de nematóides na soja em estádio de florescimento por meio de veículos aéreos não-tripulados

RESUMO: A soja é uma das principais espécies de planta cultivadas no mundo. Todavia, perdas de produtividade são ocasionadas por vários tipos de estresses, incluindo os nematoides H. glycines e P. brachyurus. Como objetivo, buscou-se determinar a melhor banda espectral para a detecção do H. glycines e P. brachyurus com o uso de modelos de regressões lineares simples e definir um modelo matemático de regressão linear múltiplo para sua detecção, no inicio do florescimento (R1). Para isto, foram definidos nove pontos de coleta em cinco reboleiras, totalizando 45 pontos. As coletas foram feitas em um padrão especifico de distâncias, de forma a ter amostras com tipos variados de populações de nematoides. Foram realizados voos com o Phantom 4 Advanced, Sequoia e Sentera sobre cada uma das reboleiras. O comprimento de onda do vermelho melhor explicou a variabilidade dos dados para H. glycines no solo e na raiz, bem como dos juvenis de segundo estádio no solo. Para P. brachyurus, a RedEdge da Sentera foi a que explicou melhor a variabilidade dos dados para nematoide na raiz e a NIR da Sequoia a que melhor explicou para juvenis no solo. Quando se utilizou um modelo matemático para a detecção do P. brachyurus e H. glycines, percebese uma grande melhora no $R^{2}$ e p-valor com relação às regressões lineares simples. No início da floração (R1), a refletância espectral da soja foi associada ao número de H. glycines e P. brachyurus no solo e nas raizes, usando sensores de baixo custo e multiespectrais.

Palavras-chave: Glycine max, drones, sensoriamento remoto, agricultura de precisão, manejo integrado.

\section{INTRODUCTION}

Soybean [Glycine $\max (\mathrm{L}$.$) Merril] is one of the$ oldest crops cultivated by humans and is currently cultivated worldwide (HYMOWITZ, 1970). Soybean is used on grainbased foods for humans and animals, and as a raw material for biofuel production (ZHANG et al., 2017).

Various types of stressors affects Soybean causing yield losses, in particular the soybean cyst nematode Heterodera glycines and the root lesion nematode Pratylenchus brachyurus (NIBLACK, 2005; WRATHER \& KOENNING, 2006; GOULART, 2008; WANG et al., 2015; PENG et al., 2016).
Heterodera glycines is a sedentary endoparasite that infects roots and may cause aboveground symptoms, including plant dwarfism, leaf chlorosis, early senescence, lower seed weight, and ultimately plant death (NIBLACK, 2005; ZHANG \& SONG, 2017). Symptoms of attack of $P$. brachyurus are characterized by spots on leaves that often change in color. Roots infected by $P$. brachyurus have reddish-brown lesions progressing toward necrosis (DIAS et al., 2010). Irregular shapes of clustered plants can be observed after infection from $H$. glycines and $P$. brachyurus, but these patterns may be similar to the symptoms from water and nutritional 
stress (BLEVINS et al., 1995). Resistant soybean cultivars can prevent yield losses, but the integration of control methods is important keep resistance (TYLKA \& MARK, 2002; CONCIBIDO et al., 2004; MITCHUM et al., 2007; NIBLACK et al., 2008).

In addition, the diagnosis of nematodeinfected areas is costly because the precise estimation of population distribution requires a large number of soil samples across the field (MARTINS et al., 2017). One way of indirectly determine nematode damage in large areas and in short time intervals is the use of remote sensing. Symptoms on leaves, nematode low mobility in soil, and plant-infested clusters are argued to enable detection of nematodes by orbital and aerial imaging, facilitating the use of imaging applications on precision agriculture (HILLNHÜTTER et al., 2012). For nematode-induced stress, several sensorbased processes were tested using terrestrial and aerial platforms (HEATH et al., 2000; NUTTER et al., 2002; LAUDIEN, 2005; HILLNHÜTTER et al., 2012). Several authors T use of remote sensors on studies evaluating asymptomatic and symptomatic plant problems (MARCASSA et al., 2006; CHO et al., 2012; HUNT et al., 2013; OUMAR et al., 2013; ASHOURLOO et al., 2016).

Among the narrow spectral bands widely used in agriculture, hyperspectral bands are widely used to determine plant canopy characteristics, which can be caused to detect various types of stressors (GEBBERS \& ADAMCHUK, 2010; MULLA, 2013; MAHLEIN et al., 2013). In short, hyperspectral remote sensing can be a valuable tool for early detection of plant disease, as the electromagnetic spectrum can detect imperceptible changes to the human eye (MAHLEIN et al., 2012; MARTINELLI et al., 2015). Spectral bands of sensors can record information from the electromagnetic spectrum within a predetermined interval of wavelengths (BENDIG et al., 2014; JANNOURA et al., 2015). The central spectral band of the sensor typically contributes to most of the spectral information within the bandwidth. For better detection of pathogens, narrow band vegetation indices (IVs) are increasingly being used. Through them, it is possible to evaluate changes in vegetation at various scales, as well as to estimate the damage caused by pathogens (MARCUSSI et al., 2010; MAHLEIN et al., 2013).

Unmanned Aerial Vehicles (UAVs), the miniaturization of spectral sensors, and new algorithms have enabled several applications of digital imaging for quick, high-precision cartographic products from large areas (COLOMINA \& MOLINA, 2014). Using remote sensing for precise pathogen detection and mapping and localized management. Relatively rapid and early identification of the spatial distribution of a disease is possible using canopy-based reflectance methods (MOSHOU et al., 2004; QIN et al., 2009; SHAFRI \& HAMDAN, 2009; SANKARAN et al., 2010). Few studies have explored the use of RGB, multispectral and hyperspectral images for detecting soybean cyst and root lesion nematode. NUTTER et al. (2002) used aerial remote sensing to quantify soybean cyst nematode population density reported and RE that $60 \%$ variability of the initial population can be explained by canopy reflectance. BAJWA et al. (2017) could distinguish a healthy soybean plant from another with cyst with high accuracy values.

The objectives of this study were to determine the best spectral band for detecting $H$. glycines and $P$. brachyurus using simple linear regression models and to determine a multiple linear regression model for their detection at the beginning of flowering (R1).

\section{MATERIALS AND METHODS}

\section{Study area}

The study area of approximately 330 hectares was located near the city of Rio Verde during the 2017/2018 growing season. This area had a dystrophic red Latosol, elevation of approximately 953 meters, slope ranging from flat (0 to $3 \%$ ) to gentle undulating ( 3 to $8 \%$ ), the average temperature of $22.3{ }^{\circ} \mathrm{C}$ and annual rainfall around 1600 millimeters (SOMA BRASIL, 2019) (Figure 1). Preliminary analysis determined that the experimental area had $H$. glycines from races 1,3 , and 6, P. brachyurus and Helicotylenchus dihystera (data not shown). Nematode species were identified under the microscope following methodology from COOLEN \& D'HERDE (1972) by trained personnel from the Phytopathology Laboratory of the Federal Institute of Goiás, in the municipality of Rio Verde, State of Goiás. The races of $H$. glycines were determined using the method described in CORDEIRO et al. (2008).

\section{Materials}

The sensors used in this study included the Sequoia, Sentera and RGB on Phantom 4 Advanced. The Sequoia had four separate sensors: green at 550 nanometers $(\mathrm{nm})$, red at $660 \mathrm{~nm}$, red edge at $735 \mathrm{~nm}$, and nir at $790 \mathrm{~nm}$. Sentera had eight sensors from the traditional spectral bands found on common sensors: 446, 548, 586, 615, 650, 661, 775, and $825 \mathrm{~nm}$. Sentera also had a NDVI sensor containing a $625 \mathrm{~nm}$ (red) and $850 \mathrm{~nm}$ (NIR) spectral bands. The NDRE 


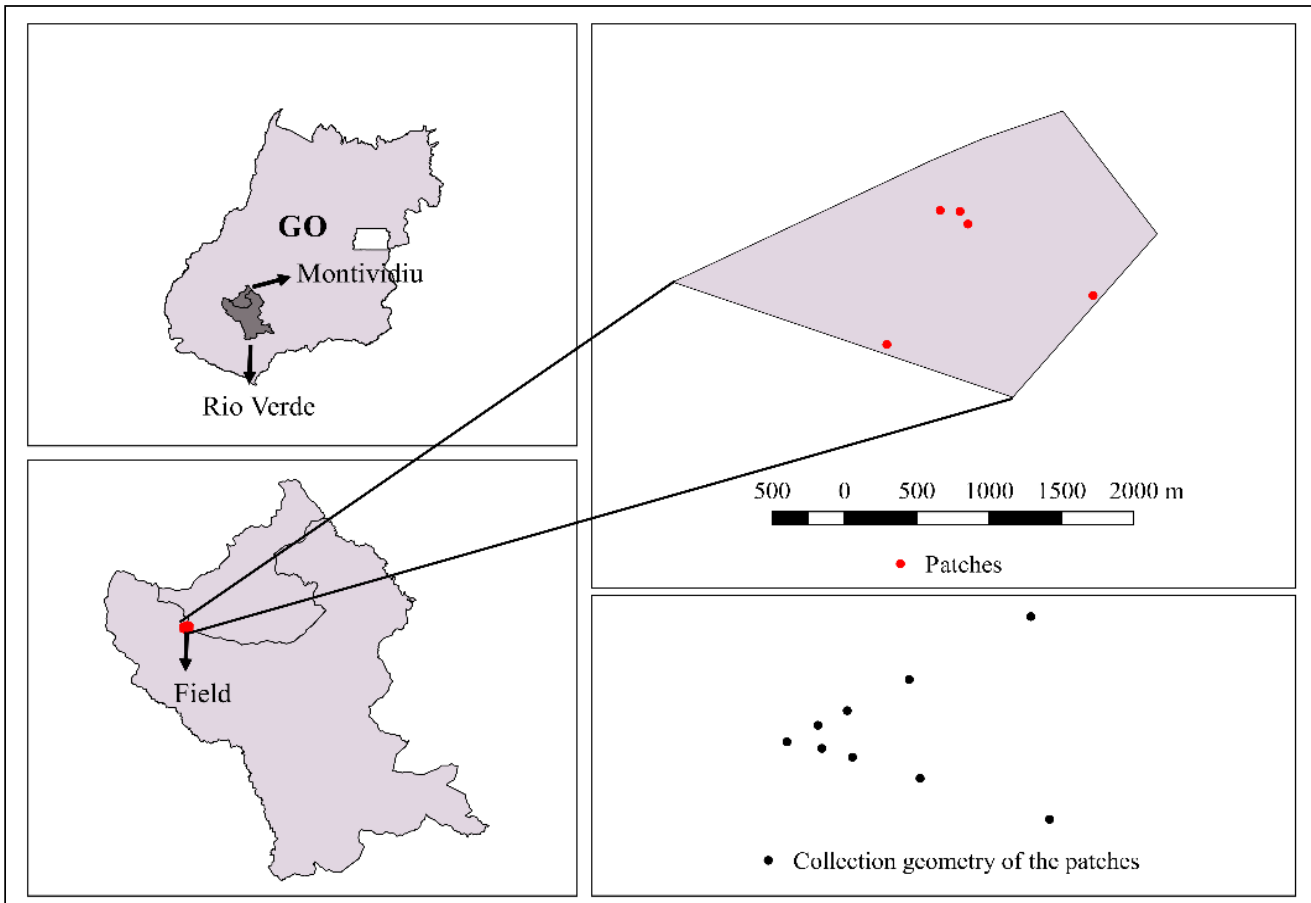

Figure 1 - Location map of the study area, as well as the sampling sites and the representation of how the sites were sampled in each patch.

sensor contained another NIR band at $840 \mathrm{~nm}(\mathrm{NIR})$ and $720 \mathrm{~nm}$ (red edge).

Although, Sequoia had the RGB sensor, this sensor was not used because it had some noise in the image. The RGB sensor onboard of Phantom 4 Advanced was not specified by the manufacturer and was, therefore, set to red-Phantom, green-Phantom, and blue-Phantom. Sequoia sensor was boarded on a Phantom 4 Advanced. Sentera sensor was boarded on the Inspire 2. For each sampling site in the patches, an A4-size white sheet was used to find the sampling sites in the images. A Garmin etrex 20 was used to find the sampling sites in the 5 nematode-infested regions.

For preparing the flight plans for RGB-Phantom and Sequoia sensors, we used the DroneDeploy application. We used the Field Agent for flight definition for Sentera. Other materials such as hoe, properly identified plastic bags, sieves, among others, were used for collecting soil, root, and plants in the field and, consequently, nematode extraction. Pix 4d software was used to create the orthorectified maps. Qgis software was used to extract pixel information from the sampling regions and to create maps. R software was used for statistical analysis ('rumor' package).
Plant height, root biomass and nematode data

A preliminary flight with the RGB sensor from the 2017/18 soybean crop was used to determine areas of interest that were potentially infested by nematodes. These areas were chosen to facilitate field sampling and increase the chances of finding higher degrees of severity (chlorosis). A total of 5 regions were selected for this research to have a significant number of samples for the elaboration of linear regressions.

Each region had 9 sampling sites. The first sampling site was at the center of the nematodeinfested region. Sampling sites at 10, 20, 40, and 80 meters were determined in two directions from the center of the region (Figure 1). The directions were set so that the sites of one patch did not coincide with another patch. The sampling sites represented high, intermediate, and low (non-significant) populations of $H$. glycines and P. brachyurus.

The cultivar MONSOY 7198 was planted on October 10, 2018. This cultivar is considered an early group of maturation, and resistant to $H$. glycines races 1 and 3. Sampling and flights were performed on the same days during the R1 stage of soybean. This reproductive stage was chosen because of less 
interference of soil reflectance than that from the vegetative stage. At each sampling site, soil samples were taken at a depth from 0 to $20 \mathrm{~cm}$ in a "V" shape, and then the soil samples were mixed homogeneously. Roots were extracted to quantify the nematodes $H$. glycines and P. brachyurus and to measure the height, dry and green mass of the canopy of six plants, as well as the dry and green mass of six roots.

The extraction of $P$. brachyurus and $H$. dihystera in soil and root was done by the methods of JENKINS (1964), and COOLEN and D'HERDE (1972). For the second stage juveniles of $H$. glycines in soil and root, the adapted methodology of JENKINS (1964) and ALFENAS (2007) was used. For cysts (viable and non-viable) in soil, the methodology adapted by ARAÚJO (2009) was used and for females in the root, the method adapted by TIHOHOD (2000).

\section{Planning and operation of the flight}

The flights were made on the same days as the collection of agronomic and nematode data, so that they were performed whenever possible between $10 \mathrm{~h} 00$ and $14 \mathrm{~h} 00$, to minimize shadow effects generated by the position of the sun in relation to the objects.

In all flight plans, side and longitudinal overlaps were set to $80 \%$ to prevent problems during the creation of the orthomosaics. Our tests using several flight overlap indicated $80 \%$ as optimal for our drones and environmental conditions. Side overlap must prevent failures between consecutive lanes because of drift caused by high winds, drone inclinations, flight height variation, and terrain elevation. In addition, using a larger side overlaps avoids using the extreme edges of images whose radial lens distortion is often greater. Longitudinal overlap is important to provide supporting points by photo triangulation of images and stereoscopic.

The flight height for all sensors was set to 40 meters, resulting in a $1.2-\mathrm{cm}$ pixel for the Phantom RGB sensor, 3.2-cm pixel for Sentera, and 4-cm pixel for Sequoia. It was not possible to obtain a cloud-free sky in all flights. However, the sampling regions were always cloud-free in the images.

\section{Flight processing and information extraction from orthomosaics}

Orthomosaic of the sampling areas was created using Pix4D software. It was necessary to extract some information associated with each image, such as camera calibration data and log file (coordinates of the center of each image and inclinations, $\omega, \phi, \kappa)$. As there was no calibration panel, digital number of the pixels were used in the analyses. Therefore, orthomosaic was imported into Qgis for using multiple spectral bands. The tool used for this was the raster calculator.

For each sampling site, a $1 \mathrm{~m}$ by $25 \mathrm{~cm}$ vector layer was created to extract the value of the corresponding pixels in each band of each sensor and obtain the reflectance average for further statistical analysis. A supervised classification removed pixels associated with soil and shadow background, leaving only pixels related to plants for the statistical analyses. The average of the pixels was obtained with the aid of the grid creation tools and statistics by zone.

\section{Statistical analysis}

Due to the large number of variables involved in this study and the search for a statistic that could best explain the behavior of the data, simple and multiple linear regressions were used. The objective of using the simple linear regression was to identify the best spectral bands for detecting the occurrence of soybean cyst nematode and root lesion nematode. In addition, the multiple regression identified the best combination of spectral bands for detecting nematodes. A forward model selection was conducted with all spectral bands and sensors to select a subset of them that would work together to characterize the variability on nematode densities. The most important spectral band was selected by the lowest P-value from the simple linear regression models. Other independent, non-redundant spectral bands were added sequentially (one-by-one) considering the lowest Mallows's Cp value (HAIR et al., 2009; GIONGO et al., 2020). Residues from the models were visually inspected for normality, independence and homoscedastic. The data transformation was not needed. Simple and multiple regression models were plotted using digital number of soybean reflectance as independent variable $(x)$ and number of nematodes as a response variable $(y)$. Only models with significant P-values $(\alpha=0.5 \%)$ are included in the tables.

\section{RESULTS AND DISCUSSION}

The dwarf plants and exposed soil within the nematode-infested regions were distinct from the other parts of the soybean field (Figure 2). This contrast offers an opportunity for growers to mapping nematodes using mathematical models and low-cost sensors such as that of Phantom 4 Advanced. The geographical information of nematode infestation 


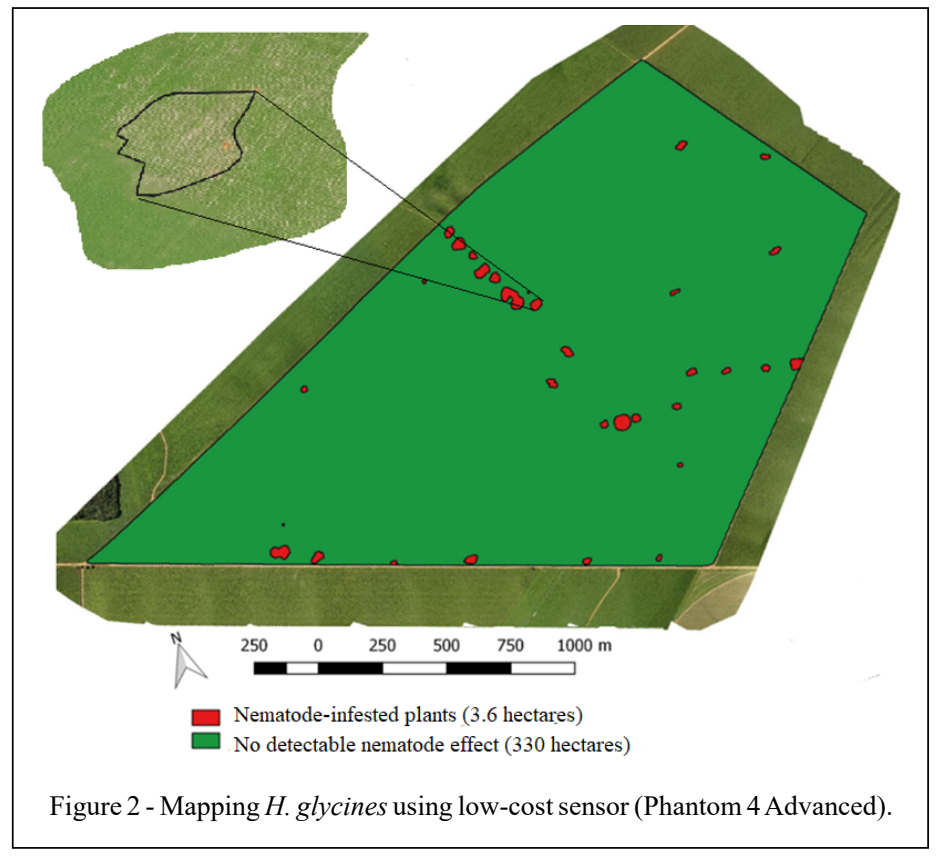

can support localized application of chemical or biological control products that can reduce the costs of controlling nematodes. Pratylenchus brachyurus was the most abundant nematode in the study with up to 126 nematodes in $100 \mathrm{~cm}^{3}$ of soil and up to 1439 nematodes in 10 grams of roots. The cultivar used in the study was races-resistant one and three; therefore, the population of $H$. glycines was considerably smaller in our evaluations, with the maximum number of viable cysts in the soil of 12 , maximum number of non-viable cysts in the soil of 91; maximum number of juveniles of $H$. glycines of 125 in the soil and 13 in the roots. We also identified $H$. glycines (races one, three, and six) and $H$. dihystera nematodes in the samples. However, $H$. dihystera was excluded in the statistical analysis because it is an ectoparasite assumed to cause non-significant damage to soybean (MANSO et al., 1994). The resistant soybean cultivar partly explained the higher numbers of juveniles and cysts of $H$. glycines in the soil than that observed in the roots.

The spectral bands at $615 \mathrm{~nm}$ and redPhantom were associated with $H$. glycines soybean cyst nematodes at all sampling regions (Table 1). The red-Phantom best explained the variability of data for juveniles and non-viable cysts (Table 1). Such a result is similar to the result of BAJWA et al. (2017) in soybean, referring to the study of simple correlation of bands with $H$. glycines and sudden death syndrome. Despite the low capability of explaining the variability on $H$. glycines data $\left(\mathrm{R}^{2}=0.197\right)$, our low-cost red-Phantom sensor detect spectral changes in soybean due to nematode injury similar to more expensive sensors (Table 1).

Juveniles of $H$. glycines from most of the sampling sites were not associated with visible symptoms and changes in plant spectral responses. Spectral bands associated with nematode injury were different between $P$. brachyurus and $H$. glycines (Table 1), indicating that spectral bands have different ability to detect plant responses to pathogens (SANKARAN et al., 2010). Because plant damage was directly associated with root nematodes rather than soil nematodes, the equations of great interest for simple linear regression for $H$. glycines are those using the red-Phantom and for root lesion nematodes, the Sentera RedEdge, as they have the best value of $\mathrm{R}^{2}$ and $\mathrm{p}$-value (Table 1).

For H.glycines, higher numbers of juveniles in roots increased the reflectance at visible spectral bands (Table 1). Increasing red reflectance may have indicated a lower biomass of shoots and roots, as well as a decrease in plant height (MARTINS et al., 2017; BAJWA et al., 2017; MAHLEIN et al., 2012). Changes in red reflectance may also be associated with chlorophyl content in the leaves (ALVES et 
Table 1 - Simple linear regressions and their coefficient of determination and significance level for nematode and agronomic variables according to bands of each sensor.

\begin{tabular}{|c|c|c|c|c|}
\hline $\begin{array}{ll}\text { Dependent } & \text { variable } \\
\text { nematode/agronomic (y) } & \end{array}$ & Independent variable $(\mathrm{x})$ & Regression equation & P-value & $\mathrm{R}^{2}$ \\
\hline \multirow{4}{*}{ Non-viable cyst } & $615 \mathrm{~nm}$ & $Y=-43.4171+0.9169 \times x$ & 0.032 & 0.081 \\
\hline & RedEdge - Sentera $(720 \mathrm{~nm})$ & $Y=-25.9480+0.7000 \times x$ & 0.041 & 0.072 \\
\hline & Nir - NDRE $(840 \mathrm{~nm})$ & $\mathrm{Y}=-34.2038+0.4268 \times \mathrm{x}$ & 0.034 & 0.079 \\
\hline & Red - Phantom & $Y=-87.5923+0.9258 \times x$ & 0.003 & 0.162 \\
\hline \multirow{2}{*}{ H. glycines in root } & $615 \mathrm{~nm}$ & $\mathrm{Y}=-4.9340+0.0827 \times \mathrm{x}$ & 0.021 & 0.096 \\
\hline & Red - Phantom & $Y=-9.0733+0.0850 \times x$ & 0.001 & 0.197 \\
\hline \multirow{2}{*}{ H. glycines in soil } & $615 \mathrm{~nm}$ & $\mathrm{Y}=-55.8575+0.9485 \times \mathrm{x}$ & 0.006 & 0.138 \\
\hline & Red - Phantom & $\mathrm{Y}=-93.7538+0.8870 \times \mathrm{x}$ & $<0.001$ & 0.222 \\
\hline \multirow{3}{*}{ P. brachyurus in root } & RedEdge - Sentera $(720 \mathrm{~nm})$ & $y=1286.9880-14.7590 \times x$ & 0.007 & 0.137 \\
\hline & Nir - NDRE $(840 \mathrm{~nm})$ & $\mathrm{y}=1374.3350-8.2390 \times x$ & 0.011 & 0.121 \\
\hline & RedEdge - Sequoia $(735 \mathrm{~nm})$ & $Y=-632.8505+0.0290 \times x$ & 0.024 & 0.091 \\
\hline P. brachyurus in soil & Air - Sequoia (790 nm) & $\mathrm{y}=99.8122-0.0024 \times x$ & 0.042 & 0.071 \\
\hline \multirow{6}{*}{ Plant height } & $615 \mathrm{~nm}$ & $y=32.5222-0.1373 \times x$ & 0.018 & 0.102 \\
\hline & Red - Sentera $(650 \mathrm{~nm})$ & $y=60.4020-0.3200 \times x$ & $<0.001$ & 0.422 \\
\hline & Blue - Sentera (446 nm) & $y=48.6091-0.2725 \times x$ & 0.022 & 0.094 \\
\hline & Red - Phantom & $y=37.7422-0.1260 \times x$ & 0.003 & 0.161 \\
\hline & RedEdge - Sequoia (735 nm) & $y=12.9613-0.0003 \times x$ & 0.005 & 0.146 \\
\hline & Air - Sequoia (790 nm) & $y=13.6545-0.0003 \times x$ & 0.015 & 0.107 \\
\hline \multirow{9}{*}{ Shoot dry mass (MSA) } & $615 \mathrm{~nm}$ & $y=3.9011-0.0203 \times x$ & 0.045 & 0.068 \\
\hline & $586-\mathrm{nm}$ & $y=5.0940-0.0177 \times x$ & 0.031 & 0.082 \\
\hline & Red - Sentera $(650 \mathrm{~nm})$ & $y=7.5385-0.0431 \times x$ & $<0.001$ & 0.245 \\
\hline & Green - Sentera $(548 \mathrm{~nm})$ & $y=6.3636-0.0259 \times x$ & 0.015 & 0.109 \\
\hline & Blue - Sentera (446 nm) & $y=7.4970-0.0537 \times x$ & 0.008 & 0.129 \\
\hline & Red - Phantom & $y=5.4740-0.0259 \times x$ & $<0.001$ & 0.236 \\
\hline & Green - Phantom & $y=5.3136-0.016 \times x$ & 0.013 & 0.113 \\
\hline & Blue - Phantom & $y=4.4609-0.0214 \times x$ & $<0.001$ & 0.210 \\
\hline & Green - Sequoia (550 nm) & $y=3.7115-0.0001 \times x$ & 0.036 & 0.077 \\
\hline \multirow{5}{*}{ Root dry mass (MSR) } & $615 \mathrm{~nm}$ & $y=10.1170-0.0634 \times x$ & 0.023 & 0.093 \\
\hline & 586-nm & $y=13.5265-0.0531 \times x$ & 0.019 & 0.100 \\
\hline & Red - Sentera $(650 \mathrm{~nm})$ & $y=14.6932-0.0751 \times x$ & 0.030 & 0.083 \\
\hline & Green - Sentera $(548 \mathrm{~nm})$ & $y=14.7055-0.0596 \times x$ & 0.046 & 0.067 \\
\hline & Blue - Phantom & $y=9.2664-0.0367 \times x$ & 0.048 & 0.066 \\
\hline \multirow{8}{*}{ Shoot green mass (MVA) } & $586-\mathrm{nm}$ & $y=7.2453-0.0237 \times x$ & 0.026 & 0.089 \\
\hline & Red - Sentera $(650 \mathrm{~nm})$ & $y=7.7008-0.0330 \times x$ & 0.043 & 0.070 \\
\hline & Green - Sentera $(548 \mathrm{~nm})$ & $y=9.9035-0.0414 \times x$ & 0.002 & 0.176 \\
\hline & Blue - Sentera (446 nm) & $y=10.1784-0.0688 \times x$ & 0.009 & 0.125 \\
\hline & Red - Phantom & $y=6.6788-0.0249 \times x$ & 0.011 & 0.119 \\
\hline & Green - Phantom & $y=8.2020-0.0264 \times x$ & 0.002 & 0.179 \\
\hline & Blue - Phantom & $y=5.9044-0.0230 \times x$ & 0.007 & 0.135 \\
\hline & Green - Sequoia $(550 \mathrm{~nm})$ & $y=5.6894-0.0001 \times x$ & 0.008 & 0.130 \\
\hline \multirow{5}{*}{ Root green mass (MVR) } & $615 \mathrm{~nm}$ & $y=31.4041-0.2121 \times x$ & 0.006 & 0.138 \\
\hline & Red - Sentera $(650 \mathrm{~nm})$ & $y=57.2280-0.3434 \times x$ & $<0.001$ & 0.253 \\
\hline & Blue - Sentera (446 nm) & $y=50.3016-0.3554 \times x$ & 0.029 & 0.085 \\
\hline & Red - Phantom & $y=40.8630-0.2072 \times x$ & $<0.001$ & 0.246 \\
\hline & Blue - Phantom & $y=26.3539-0.1318 \times x$ & 0.011 & 0.120 \\
\hline
\end{tabular}

al., 2015). For P. brachyurus, higher numbers of nematodes in roots increased reflectance at the red edge (Table 1). Stepwise multiple linear regression for detecting $P$. brachyurus and $H$. glycines improved $\mathrm{R}^{2}$ in relation to simple linear regressions. Multi-band regression models also improved detection of injury from soybean aphids Aphis glycines (ALVES et al., 2018). For P. brachyurus, the most important spectral range was outside the visible spectral range. For H. glycines, the visible wavelengths were the most important spectral bands to estimate nematode injury on soybean (Table 2).

Ciência Rural, v.51, n.5, 2021. 
Table 2 - Stepwise mathematical model for detecting P. brachyurus and H. glycines.

\begin{tabular}{lcc}
\hline Dependent variable & Mathematical model & $\mathrm{R}^{2}$ \\
\hline $\begin{array}{l}\text { H. } \text { glycines in root } \\
\text { P. brachyurus in root }\end{array}$ & $\mathrm{y}=8.4733+(-0.0988 \times$ Red_Sentera $)+(0.1330 \times$ Red_Phantom $)+(-0.1292 \times$ & $<0.001$ \\
Green_Phantom $)+(0.1081 \times$ Blue_Phantom $)$ & 0.327 \\
\hline
\end{tabular}

\section{CONCLUSION}

Soybean canopy reflectance from flowering growth stage (R1) was associated with the number of $H$. glycines and $P$. brachyurus on soil and roots. Therefore, low-cost sensors at the visible spectral range were sufficient to estimate $H$. glycines, but multispectral sensors were necessary to estimate $P$. brachyurus. Although, p-values indicated a significant association between soybean reflectance and nematode numbers, a better understanding of other factors affecting soybean canopy reflectance is still necessary to improve our models.

\section{ACKNOWLEDGEMENTS}

This research was supported by equipment and laboratories from the Instituto Federal Goiano (IF) and the Polo de Inovação of the Rio Verde - Go campus. In addition, Coordenação de Aperfeiçoamento de Pessoal de Nível Superior (CAPES) financed the research grants. Thanks to the Federal Institute Goiano Rio Verde campus and Proppi for supporting the study and translation of the article

\section{DECLARATION OF CONFLICTS OF} INTEREST

The authors declare no conflict of interest. The founding sponsors had no role in the design of the study; in the collection, analysis, or interpretation of data; in the writing of the manuscript, and in the decision to publish the results.

\section{AUTHORS' CONTRIBUTIONS}

All authors contributed equally for the conception and writing of the manuscript. All authors critically revised the manuscript and approved of the final version.

\section{REFERENCES}

ALFENAS, A.C. Métodos em fitopatologia. 2 ed. Viçosa: Universidade Federal de Viçosa, 2007. 382p.

ALVES, T. M. et al. Soybean rapid (Hemiptera: Aphididae) affects soybean spectral reflectance. Journal of Economic Entomology, v.108, n.6, p.2655-2664, 2015. Available from: $<$ https://doi.org/10.1093/jee/ tov250>. Accessed: Mar. 12, 2020. doi: 10.1093/jee/tov250.

ALVES, T.M., et al. Optimizing band selection for spectral detection of Aphis glycines Matsumura in soybean. Pest Management Science, v.75, n.4, p.942-949, 2018. Available from: <https:/ onlinelibrary.wiley.com/doi/full/10.1002/ps.5198>. Accessed: Jan. 08, 2020. doi: $10.1002 /$ ps.5198.

ARAÚJO, F.G.D. Quantificação de machos e fêmeas de Heterodera glycines (Ichinohe, 1952) em cultivar de soja resistentes e suscetíveis. 2009. 39f. Dissertação (MestradoCiências Agrárias) - Curso de Pós-graduação - Ciências Agrárias - Agronomia, Universidade Federal de Goiás.

ASHOURLOO, D. et al. Developing an index for detection and identification of disease stages. IEEE Geoscience and Remote Sensing Letters, v.13, n.6, p.851-855, 2016. Available from: $<$ https://ieeexplore.iee.org/stamp/stamp. jsp?tp=\&arnumber $=7466803>$. Accessed: Feb. 02, 2020. doi: 10.1109/LGRS.2016.2550529.

BAJWA, S. G. et al. Soybean disease monitoring with leaf reflectance. Remote Sensing, v.9, n.2, p.127, 2017. Available from: <https://www.mdpi.com/2072-4292/9/2/127>. Accessed: Nov. 22, 2019. doi: 10.3390/rs9020127.

BENDIG, J. et al. Estimating biomass of barley using crop surface models (CSMs) derived from UAV-based RGB imaging. Remote Sensing, v.6, n.11, p.10395-10412, 2014. Available from: $<$ https:// www.mdpi.com/2072-4292/6/11/10395>. Accessed: Nov. 28, 2019. doi: $10.3390 /$ rs61110395.

BLEVINS, D. G. et al. Macronutrient uptake, translocation, and tissue concentration of soybeans infested with the soybean cyst nematode and elemental composition of cysts isolated from roots. Journal of plant nutrition, v.18, n.3, p.579-591, 1995. Available from: <https://www.tandfonline.com/doi/ abs/10.1080/01904169509364924>. Accessed: Dec. 19, 2019. doi: $10.1080 / 01904169509364924$.

$\mathrm{CHO}, \mathrm{M}$. A. et al. Potential utility of the spectral red-edge region of SumbandilaSat imagery for assessing indigenous forest structure and health. International journal of applied earth observation and Geoinformation, v.16, p.85-93, 2012. Available from: $<$ https://www. sciencedirect.com/science/article/abs/pii/S0303243411001978>. Accessed: Jan. 25, 2020. doi: 10.1016/j.jag.2011.12.005.

COLOMINA, I.; MOLINA, P. Unmanned aerial systems for photogrammetry and remote sensing A review. ISPRS Journal of photogrammetry and remote sensing, v.92, p.79-97, 2014. 
Available from: $<$ https://doi.org/10.1016/j.isprsjprs.2014.02.013>. Accessed: Jan. 25, 2020. doi: 10.1016/j.isprsjprs.2014.02.013.

CONCIBIDO, V. C. Et al. A decade of QTL mapping for cyst nematode resistance in soybean. Crop science, v.44, n.4, p.11211131, 2004. Available from: <https://dl.sciencesocieties.org/ publications/cs/abstracts/44/4/1121>. Accessed: Dec. 14, 2019. doi: $10.2135 /$ cropsci.2004.1121

COOLEN, WA. D'HERDE, CJ. A method for the quantitative extraction of nematodes from the plant tissue. 1 ed. Merelbeke, Bélgica: Ghent, 1972. 77p.

CORDEIRO, M. C. R. et al. Identificação molecular de Heterodera glycines, o Nematoide de cisto da soja. 1 ed. Planaltina, DF: Embrapa Cerrado (INFOTECA-E), 2008. 16p.

DIAS, W. P. et al. Nematóides em soja: identificação e controle. 1 ed. Londrina, PR: Embrapa Soja-Circular Técnica (INFOTECA-E), 2010, 7p.

GEBBERS, R.; ADAMCHUK, V. I. Precision agriculture and food security. Science, v.327, n.5967, p.828-831, 2010. Available from: <https://science.sciencemag.org/content/327/5967/828+>. Accessed: Mar. 18, 2020. doi: 10.1126/science.1183899.

GIONGO, P. R. et al. Predição de dados agronômicos em goiabeiras e separação de alvos por meio de Veículo Aéreo Não Tripulado. Scientia Plena, v.16, n.14, 2020. Available from: $<$ https://scientiaplena.org.br/sp/article/view/5238>. Accessed: Mar. 11, 2020. doi: 10.14808/sci.plena.2020.040202.

GOULART, A. M. C. Aspectos gerais sobre nematoides das lesões radiculares (gênero Pratylenchus). 1 ed. Planaltina: Embrapa Cerrados-Documentos (INFOTECA-E), 2008. 30p.

HAIR, J. F. et al. Análise multivariada de dados. 6 ed. Porto Alegre: Bookman editora, 2009. 679p. 2020.

HEATH, W. L. et al. The potential use of spectral reflectance from the potato crop for remote sensing of infection by potato cyst nematodes. Aspects of Applied Biology, n.60, p.185-188, 2000. Available from: <https://www.cabdirect.org/cabdirect/ abstract/20001701735>. Accessed: Nov. 21, 2019. doi: 20001701735.

HILLNHÜTTER, C et al. Use of imaging spectroscopy to discriminate symptoms caused by Heterodera schachtii and Rhizoctonia solani on sugar beet. Precision Agriculture, v.13, n.1, p.17-32, 2012. Available from: <https://link.springer.com/ article/10.1007/s11119-011-9237-2>. Accessed: Dec. 12, 2019. doi: 10.1007/s11119-011-9237-2.

HUNT JR, E. R. et al. A visible band index for remote sensing leaf chlorophyl content at the canopy scale. International Journal of Applied Earth Observation and Geoinformation, v.21, p.103-112, 2013. Available from: <https://doi.org/10.1016/j. jag.2012.07.020>. Accessed: Dec. 02, 2019. doi: 10.1016/j. jag.2012.07.020.

HYMOWITZ, T. On the domestication of the soybean. Economic botany, v.24, n.4, p.408-421, 1970. Available from: <https://link. springer.com/article/10.1007/BF02860745>. Accessed: Dec. 15, 2019.

JANNOURA, R. et al. Monitoring of crop biomass using true color aerial photographs taken from a remote controlled helicopter. Biosystems Engineering, v.129, p.341-351, 2015. Available from: <https://www.sciencedirect.com/science/article/ pii/S1537511014001998>. Accessed: Nov. 20, 2019. doi: 10.1016/j.biosystemseng.2014.11.007.

JENKINS, W.R. Et al. A rapid centrifugal-flotation technique for separating nematodes from soil. Plant disease reporter, v.48, n.9, 1964. Available from: <https://www.cabdirect.org/ cabdirect/abstract/19650801105>. Accessed: Dec. 05, 2019. doi: 19650801105

LAUDIEN, R. Entwicklung lines GIS-gestützten schlagbezogenen Führungs information systems für die Zuckerwirtschaft. Universitat Hohenheim. 2005. Available from: $<$ http://opus.uni-hohenheim.de/volltexte/2005/87>. Accessed: Dec. 05, 2019

MAHLEIN, A. K et al. Recent advances in sensing plant diseases for precision crop protection. European Journal of Plant Pathology, v.133, n.1, p.197-209, 2012. Available from: <https:// link.springer.com/article/10.1007/s10658-011-9878-z>. Accessed: Jan. 11, 2020. doi: 10.1007/s10658-011-9878-z.

MAHLEIN, A. K. et al. Development of spectral indices for detecting and identifying plant diseases. Remote Sensing of Environment, v.128, p.21-30, 2013. Available from <https://www. sciencedirect.com/science/article/abs/pii/S0034425712003793>. Accessed: Oct. 10, 2019. doi: 10.1016/j..rse.2012.09.019

MANSO, E. C. et al. Catálogo de nematóides fitoparasitos encontrados associados a diferentes tipos de plantas no Brasil. Brasilia: EMBRAPA-SPI, 1994, 488p.

MARCASSA, L. G. et al. Fluorescence spectroscopy applied to orange trees. Laser physics, v.16, n.5, p.884-888, 2006. Available from: <https://link.springer.com/article/10.1134/ S1054660X06050215>. Accessed: Jan. 29, 2020. doi: 10.1134/ S1054660X06050215.

MARCUSSI, A. B. et al. Utilização de índices de vegetação para os sistemas de informação geográfica - Use of índex vegetation for the geographic information system. Caminhos de geografia, v.11, n.35, 2010. Available from: <http://www.seer.ufu.br/index.php/ caminhosdegeografia/article/view/16000>. Accessed: Oct. 16, 2019.

MARTINELLI, F. et al. Advanced methods of plant disease detection. A review. Agronomy for Sustainable Development, v.35, n.1, p.1-25, 2015. Available from: <https://link.springer.com/ article/10.1007/s13593-014-0246-1>. Accessed: Dec. 30, 2019. doi: $10.1007 / \mathrm{s} 13593-014-0246-1$

MARTINS, G. D. et al. Detecting and mapping root-knot nematode infection in the coffee crop using remote sensing measurements. IEEE Journal of Selected Topics in Applied Earth Observations and Remote Sensing, v.10, n.12, p.5395-5403, 2017. Available from: <https://ieeexplore.iee.org/abstract/document/8016326>. Accessed: Dec. 31, 2019. doi: 10.1109/JSTARS.2017.2737618.

MITCHUM, M. G. et al. Variability in distribution and virulence phenotypes of Heterodera glycines in Missouri during 2005. Plant Disease, v.91, n.11, p.1473-1476, 2007. Available from: $<$ https:// apsjournals.apsnet.org/doi/abs/10.1094/PDIS-91-11-1473>. Accessed: Dec. 30, 2019. doi: 10.1094/PDIS-91-11-1473.

MOSHOU, D. et al. Automatic detection of 'yellow rust'in wheat using reflectance measurements and neural networks. 
Computers and electronics in agriculture, v.44, n.3, p.173-188, 2004. Available from: <https://www.sciencedirect.com/science/ article/pii/ S0168169904000705>. Accessed: Dec. 31, 2019. doi: 10.1016/j.compag.2004.04.003.

MULLA, D. J. Twenty-five years of remote sensing in precision agriculture: Key advances and remaining knowledge gaps. Biosystems engineering, v.114, n.4, p.358-371, 2013. Available from: $\quad<$ https://doi.org/10.1016/j.biosystemseng.2012.08.009>. Accessed:Oct.29,2019.doi:10.1016/j.biosystemseng.2012.08.009.

NIBLACK, T. L. et al. Shift in the virulence of soybean cyst nematode is associated with use of resistance from PI 88788. Plant Health Progress, v.9, n.1, p.29, 2008. Available from: <https:// apsjournals.apsnet.org/doi/abs/10.1094/PHP-2008-0118-01-RS> Accessed: Oct 02, 2019. doi: 10.1094/PHP-2008-0118-01-RS.

NIBLACK, T. L. Soybean cyst nematode management reconsidered. Plant disease, v.89, n.10, p.1020-1026, 2005. Available from: <https://apsjournals.apsnet.org/doi/abs/10.1094/ PD-89-1020 >. Accessed: Dec. 01, 2019. doi: 10.1094/PD-89-1020.

NUTTER JR, F. W. et al. Use of remote sensing to detect soybean cyst nematode-induced plant stress. Journal of Nematology, v.34, n.3, p.222, 2002. Available from <https:/www.ncbi.nlm.nih.gov/ pmc/articles/PMC2620572/>. Accessed: Nov. 02, 2019.

OUMAR, Z. et al. Predicting Thaumastocoris peregrinus damage using narrow band-normalized and hyperspectral indices using field spectra resampled to the Hyperion sensor. International Journal of Applied Earth Observation and Geoinformation, v.21, p.113-121, 2013. Available from: <https://doi.org/10.1016/j. jag.2012.08.006>. Accessed: Nov. 29, 2019. doi: 10.1016/j. jag.2012.08.006

PENG, D. L. et al. First report of soybean cyst nematode (Heterodera glycines) on soybean from Gansu and Ningxia China. Plant disease, v.100, n.1, p.229-229, 2016. Available from: < https://apsjournals.apsnet.org/doi/full/10.1094/PDIS-0415-0451-PDN $>$. Accessed: Nov. 28, 2019. doi: 10.1094/PDIS04-15-0451-PDN

Pix4D. Pix4D - Simply powerful, 2017. Available from: <www. pix4d.com>.

Qgis Development Team. QGIS Version 2.18. 22. Geographic Information System. Open Source Geospatial Foundation Project. 2018. Available from: <https://www.qgis.org/pt BR/ site/>.

QIN, J. et al. Detection of citrus canker using hyperspectral reflectance imaging with spectral information divergence. Journal of food engineering, v.93, n.2, p.183-191, 2009. Available from: <https://doi.org/10.1016/j.jfoodeng.2009.01.014>. Accessed: Dec. 03, 2019. doi: 10.1016/j.jfoodeng.2009.01.014.

R Development Core Team. R: A language and environment for the statistical computing. R Foundation for Statistical Computing, Vienna, 2018. Available from $<$ https://www.rproject.org/>.

SANKARAN, S. et al. A review of advanced techniques for detecting plant diseases. Computers and Electronics in Agriculture, v.72, n.1, p.1-13, 2010. Available from $<$ https://doi. org/10.1016/j.compag.2010.02.007>. Accessed: Nov. 06, 2019. doi: 10.1016/j.compag.2010.02.007

SHAFRI, H. Z. M; HAMDAN, N. Hyperspectral imagery for mapping disease infection in soil palm plantationusing vegetation indices and red edge techniques. American Journal of Applied Sciences, v.6, n.6, p.1031, 2009. Available from: <https://www. cabdirect.org/cabdirect/abstract/20093141057>. Accessed: Oct. 25, 2019. doi: 20093141057

SOMA BRASIL - Sistema de Observação e Monitoramento da Agricultural no Brasil. 2019. Available from: <http://mapas. cnpm.embrapa.br/somabrasil>.

TIHOHOD, D. Nematologia agrícola aplicada. 2 ed. Jaboticabal: Funep. 2000.

TYLKA, GL.; MARK. PM. Soybean cyst nematode-resistant soybean varieties for Iowa. Iowa State University, University Extension. 2002.

WANG, et al. Genetic structure analysis of populations of the soybean cyst nematode, Heterodera glycines, from north China. Nematology, v.17, n.5, p.591-600, 2015. Available from: <https:// doi.org/10.1163/15685411-00002893>. Accessed: Oct. 29, 2019. doi: $10.1163 / 15685411-00002893$

WRATHER, JA. KOENNING, SR. Estimates of disease effects on soybean yields in the United States 2003 to 2005. Journal of nematology, v.38, n.2, p.173, 2006. Available from: <https://www. ncbi.nlm.nih.gov/pmc/articles/PMC2586459/>. Accessed: Oct. 28, 2019. doi: .PMC2586459.

ZHANG, H. et al. Genetic architecture of wild soybean (Glycine soja) response to soybean cyst nematode (Heterodera glycines). Molecular Genetics and Genomics, v.292, n.6, p.1257-1265, 2017. Available from: $\quad<$ https://link.springer.com/article/10.1007/s00438-0171345-x>. Accessed: Dec. 01, 2019. doi: 10.1007/s00438-017-1345-x.

ZHANG, H.; SONG, BAO-HUA. RNA-seq data comparisons of wild soybean genotypes in response to soybean cyst nematode (Heterodera glycines). Genomics data, v.14, p.36-39, 2017. Available from: <https://doi.org/10.1016/j.gdata.2017.08.001>. Accessed: Dec. 01, 2019. doi: 10.1016/j.gdata.2017.08.001. 